\title{
Biosynthesis of Fluorinated Peptaibols Using a Site-Directed Building Block Incorporation Approach
}

\author{
José Rivera-Chávez, ${ }^{\dagger}$ Huzefa A. Raja, ${ }^{\dagger}$ Tyler N. Graf, ${ }^{\dagger}$ Joanna E. Burdette, $^{\ddagger}$ Cedric J. Pearce, ${ }^{\S}$
} and Nicholas H. Oberlies $*{ }^{*} \dagger$ (1)

\begin{abstract}
${ }^{\dagger}$ Department of Chemistry and Biochemistry, University of North Carolina at Greensboro, P.O. Box 26170, Greensboro, North Carolina 27412, United States

${ }^{*}$ Department of Medicinal Chemistry and Pharmacognosy, University of Illinois at Chicago, Chicago, Illinois 60612, United States

${ }^{\S}$ Mycosynthetix, Inc., 505 Meadowlands Drive, Suite 103, Hillsborough, North Carolina 27278, United States
\end{abstract}

\section{Supporting Information}

ABSTRACT: Synthetic biological approaches, such as sitedirected biosynthesis, have contributed to the expansion of the chemical space of natural products, making possible the biosynthesis of unnatural metabolites that otherwise would be difficult to access. Such methods may allow the incorporation of fluorine, an atom rarely found in nature, into complex secondary metabolites. Organofluorine compounds and secondary metabolites have both played pivotal roles in the development of drugs; however, their discovery and development are often via nonintersecting tracks. In this context, we used the biosynthetic machinery of Trichoderma arundinaceum (strain MSX70741) to incorporate a fluorine atom into peptaibol-type molecules in a site-selective manner. Thus, fermentation of strain MSX70741 in media containing ortho- and meta-F-phenylalanine resulted in the biosynthesis of two new fluorine-containing alamethicin F50 derivatives. The fluorinated products were characterized using spectroscopic (1D and 2D NMR, including ${ }^{19} \mathrm{~F}$ ) and spectrometric $\left(\right.$ HRESIMS $/ \mathrm{MS}^{\mathrm{n}}$ ) methods, and their absolute configurations were established by Marfey's analysis. Fluorine-containing alamethicin F50 derivatives exhibited potency analogous to the nonfluorinated parent when evaluated against a panel of human cancer cell lines. Importantly, the biosynthesis of fluorinated alamethicin F50 derivatives by strain MSX70741 was monitored in situ using a droplet-liquid microjunction-surface sampling probe coupled to a hyphenated system.

$\mathrm{B}$ ased on the literature and Dictionary of Natural Products, approximately 250000 secondary metabolites have been isolated from plants, microorganisms, and other sources (particularly marine life). ${ }^{1,2}$ Of these, about 4700 are halogenated, ${ }^{3}$ and just 5 contain a fluorine atom, ${ }^{4-7}$ with no reports of natural fluorometabolites derived from fungi. Nature has been a fertile source for drug leads, particularly in the realms of anticancer and antimicrobial agents. ${ }^{8-11}$ Alternatively, drugs that include at least one fluorine atom ( 274 up to $2009^{12}$ ) represent approximately $25-30 \%$ of pharmaceuticals, ${ }^{13}$ including some of the top-selling drugs, such as sofosbuvir (Sovaldi; annual revenue of $\$ 9.4$ billion in the U.S.), rosuvastatin (Crestor; annual revenue of $\$ 8.5$ billion), and sitagliptin (Januvia; annual revenue of $\$ 5.0$ billion). ${ }^{13-15}$ However, these two classes of molecules do not often intersect, perhaps limiting the combination of privileged scaffolds in natural products ${ }^{16-18}$ with the beneficial properties of fluorine atoms in medicinal chemistry. ${ }^{13}$

The high electronegativity, small atomic radius, and low polarizability of the $\mathrm{C}-\mathrm{F}$ bond are some of the unique features that make fluorine so attractive from the point of view of medicinal chemistry, ${ }^{19,20}$ such that, the benefits of incorpo- ration in lead molecules or drugs could impact drastically on physicochemical properties, resulting in changes in absorption, distribution, metabolism, and molecular interactions in vivo ${ }^{21}$ and in vitro. ${ }^{22}$ Due to the potential of fluorine-containing molecules in drug discovery, there has been a focus on the development of new synthetic and semisynthetic strategies to incorporate this atom into organic molecules, particularly in a site selective manner. ${ }^{13,23,24}$ However, the incorporation of a fluorine atom into structurally complex natural products remains a challenge, likely because of the perception that most of the fluorination reagents could degrade the parent molecule provided by nature. ${ }^{25}$

An alternative approach to modify natural product scaffolds is to employ precursor-directed biosynthesis, ${ }^{26}$ using the biosynthetic machinery of microorganisms to incorporate fluorinated building blocks into natural products. ${ }^{27-30}$ This technique has been widely used in the past, generating a vast number of microbial natural product analogues, with cyclo-

Received: March 5, 2017

Published: June 8, 2017 

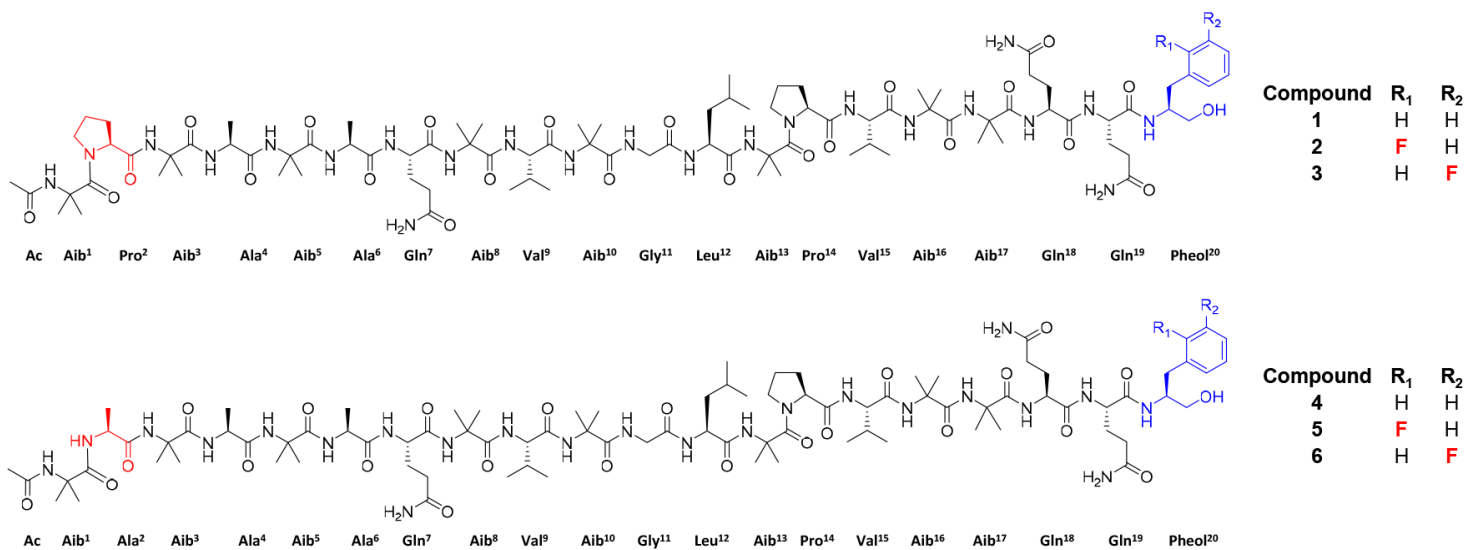

Figure 1. Structures of alamethicin F50 (1), ortho-F-Pheol alamethicin F50 (2), meta-F-Pheol alamethicin F50 (3), trichokonin VI (4), ortho-F-Pheol trichokonin VI (5), and meta-F-Pheol trichokonin VI (6). The amino acid residue targeted for modification is highlighted in blue, whereas the red residues highlight the difference between alamethicin F50 (1) and trichokonin VI (4).

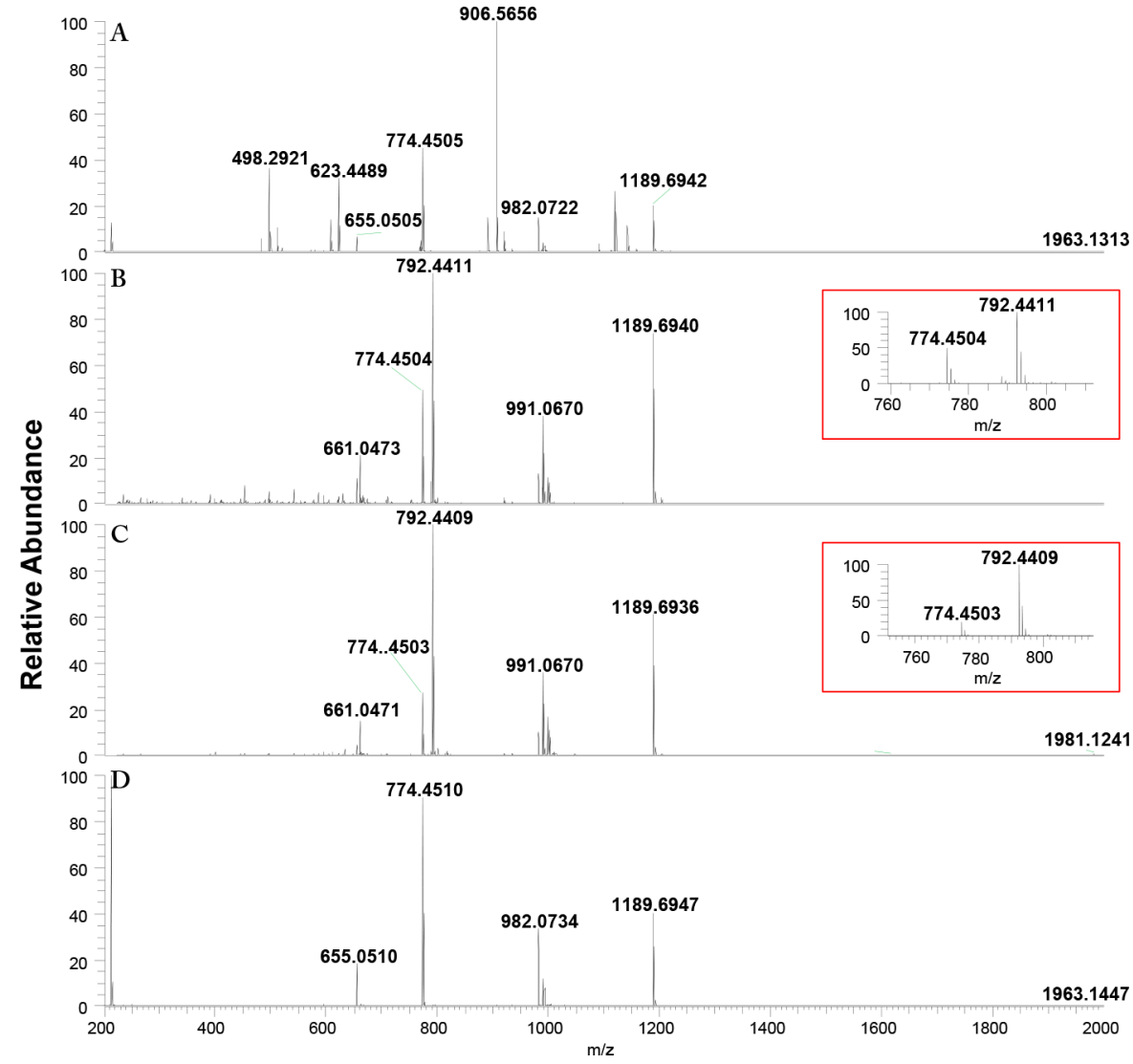

Figure 2. (A) Full-scan MS data of MSX70741 grown in PDA medium (control). (B) Full-scan MS data of MSX70741 grown in PDA supplemented with a racemic mixture of ortho-F-DL-Phe. (C) Full-scan MS data of MSX70741 grown in PDA supplemented with a racemic mixture of meta-F-DLPhe. (D) Full-scan MS data of MSX70741 grown in PDA supplemented with a racemic mixture of para-F-DL-Phe. All cultures were sampled in situ using a droplet-liquid microjunction-surface sampling probe (droplet-LMJ-SSP) coupled to a hyphenated system (UPLC-PDA-HRMS-MS/ MS). In panels $\mathrm{B}$ and $\mathrm{C}$, the peaks corresponding to the fragment $\mathrm{b}_{7}{ }^{+}(\mathrm{m} / z 792.4411$ and 792.4409 for 2 and 3, respectively), indicating the incorporation of fluorine $\left({ }^{19} \mathrm{~F}\right)$, are boxed in red. Note, the peak at $m / z 906.5656$ in panel A is not associated with the targeted molecule.

sporins likely being one of the most explored examples. ${ }^{26,31,32}$ There are challenges with this approach, because the building block selected for fluorine incorporation may not be able to compete with the natural moiety, or simply not be compatible with the enzymes involved in the biosynthesis of the desired product. Another challenge is that, in many of the cases, the organisms must be genetically modified in order to disrupt the biosynthetic pathway, so as to permit the incorporation of the fluorinated building blocks. ${ }^{25,28-30,33-35}$

To probe the applicability of precursor-directed biosynthesis with fungal cultures, and in order to contribute to the expansion of the chemical space of natural products, ${ }^{8,36,37}$ a site-directed building block incorporation approach was applied to a wild type ascomycete using fluorinated amino acids as the source of fluorine. Previously, we reported the isolation of 
Table 1. NMR Data for Alamethicin F50 (1), ortho-F-Pheol Alamethicin F50 (2), and meta-F-Pheol Alamethicin F50 (3) ${ }^{a}$

\begin{tabular}{|c|c|c|c|c|c|c|c|}
\hline \multirow[b]{2}{*}{ residue } & \multirow[b]{2}{*}{ position } & \multicolumn{3}{|c|}{2} & \multicolumn{3}{|c|}{3} \\
\hline & & $\delta_{\mathrm{C}}$ & type & $\delta_{\mathrm{H}}, \mathrm{m}(J$ in $\mathrm{Hz})$ & $\delta_{\mathrm{C}}$ & type & $\delta_{\mathrm{H}}, \mathrm{m}(J$ in $\mathrm{Hz})$ \\
\hline \multirow[t]{2}{*}{ Ac } & 1 & 172.5 & C & & 172.5 & $\mathrm{C}$ & \\
\hline & 2 & 22.4 & $\mathrm{CH}_{3}$ & $2.05, s$ & 22.4 & $\mathrm{CH}_{3}$ & $2.05, s$ \\
\hline \multirow[t]{5}{*}{$\mathrm{Aib}^{1}$} & 1 & 175.5 & $\mathrm{C}$ & & 175.5 & $\mathrm{C}$ & \\
\hline & 2 & 57.4 & $\mathrm{C}$ & & 57.4 & $\mathrm{C}$ & \\
\hline & 3 & 23.8 & $\mathrm{CH}_{3}$ & $1.46, s$ & 23.8 & $\mathrm{CH}_{3}$ & $1.46, s$ \\
\hline & 4 & 26.6 & $\mathrm{CH}_{3}$ & $1.53, s$ & 26.6 & $\mathrm{CH}_{3}$ & $1.54, s$ \\
\hline & $\mathrm{NH}$ & & & $8.63, \mathrm{~s}$ & & & $8.64, \mathrm{~s}$ \\
\hline \multirow[t]{5}{*}{$\mathrm{Pro}^{2}$} & 1 & 175.6 & $\mathrm{C}$ & & 175.6 & $\mathrm{C}$ & \\
\hline & 2 & 65.7 & $\mathrm{CH}$ & $4.25, t(8.4)$ & 65.7 & $\mathrm{CH}$ & $4.25, t(8.4)$ \\
\hline & 3 & 29.7 & $\mathrm{CH}_{2}$ & $\begin{array}{l}1.80, m \\
2.34, m\end{array}$ & 29.7 & $\mathrm{CH}_{2}$ & $\begin{array}{l}1.80, m \\
2.34, m\end{array}$ \\
\hline & 4 & $27.1^{b}$ & $\mathrm{CH}_{2}$ & $\begin{array}{l}1.97, m \\
2.08, m\end{array}$ & $27.1^{b}$ & $\mathrm{CH}_{2}$ & $\begin{array}{l}1.97, m \\
2.08, m\end{array}$ \\
\hline & 5 & 49.9 & $\mathrm{CH}_{2}$ & $\begin{array}{c}3.48, t d,(10.5,6.3) \\
3.95, m\end{array}$ & 49.9 & $\mathrm{CH}_{2}$ & $\begin{array}{c}3.49, t d,(10.5,6.3,) \\
3.95, m\end{array}$ \\
\hline \multirow[t]{5}{*}{$\mathrm{Aib}^{3}$} & 1 & 178.5 & $\mathrm{C}$ & & 178.5 & $\mathrm{C}$ & \\
\hline & 2 & 57.4 & $\mathrm{C}$ & & 57.4 & $\mathrm{C}$ & \\
\hline & 3 & 23.1 & $\mathrm{CH}_{3}$ & $1.54, s$ & 23.1 & $\mathrm{CH}_{3}$ & $1.54, s$ \\
\hline & 4 & 27.4 & $\mathrm{CH}_{3}$ & $1.56, s$ & 27.4 & $\mathrm{CH}_{3}$ & $1.56, s$ \\
\hline & $\mathrm{NH}$ & & & $7.62, s$ & & & $7.62, s$ \\
\hline \multirow[t]{4}{*}{$\mathrm{Ala}^{4}$} & 1 & 177.2 & $\mathrm{C}$ & & 177.2 & $\mathrm{C}$ & \\
\hline & 2 & 54.1 & $\mathrm{CH}$ & $4.09, m$ & 54.1 & $\mathrm{CH}$ & $4.09, m$ \\
\hline & 3 & 17.1 & $\mathrm{CH}_{3}$ & $1.48, d,(7.7)$ & 17.0 & $\mathrm{CH}_{3}$ & $1.48, d,(7.7)$ \\
\hline & $\mathrm{NH}$ & & & $7.56, d,(5.6)$ & & & $7.56, d,(5.6)$ \\
\hline \multirow[t]{5}{*}{$\mathrm{Aib}^{5}$} & 1 & 177.8 & $\mathrm{C}$ & & 177.8 & $\mathrm{C}$ & \\
\hline & 2 & 57.3 & $\mathrm{C}$ & & 57.3 & $\mathrm{C}$ & \\
\hline & 3 & 23.1 & $\mathrm{CH}_{3}$ & $1.54, s$ & 23.1 & $\mathrm{CH}_{3}$ & $1.54, s$ \\
\hline & 4 & 27.1 & $\mathrm{CH}_{3}$ & $1.56, s$ & 27.1 & $\mathrm{CH}_{3}$ & $1.56, s$ \\
\hline & $\mathrm{NH}$ & & & $7.93, s$ & & & $7.93, s$ \\
\hline \multirow[t]{4}{*}{$\mathrm{Ala}^{6}$} & 1 & 178.1 & $\mathrm{C}$ & & 178.1 & $\mathrm{C}$ & \\
\hline & 2 & 53.9 & $\mathrm{CH}$ & $4.02, m$ & 53.8 & $\mathrm{CH}$ & $4.01, m$ \\
\hline & 3 & 16.9 & $\mathrm{CH}_{3}$ & $1.53, d$, overlapped & 16.9 & $\mathrm{CH}_{3}$ & $1.53, d$, overlapped \\
\hline & $\mathrm{NH}$ & & & 7.92, brs & & & 7.91, brs \\
\hline \multirow[t]{10}{*}{$\mathrm{G} \ln ^{7}$} & 1 & 175.8 & $\mathrm{C}$ & & 175.8 & $\mathrm{C}$ & \\
\hline & 2 & 58.1 & $\mathrm{CH}$ & 3.94, $m$ & 58.1 & $\mathrm{CH}$ & 3.94, $m$ \\
\hline & 3 & 27.1 & $\mathrm{CH}_{2}$ & $2.15, m$ & 27.3, & $\mathrm{CH}_{2}$ & $2.15, m$ \\
\hline & & & & $2.30, m$ & & & $2.30, m$ \\
\hline & 4 & 32.6 & $\mathrm{CH}_{2}$ & $2.34, m$ & 32.5 & $\mathrm{CH}_{2}$ & $2.34, m$ \\
\hline & & & & $2.54, d d d,(15.4,9.8,5.6)$ & & & $2.54, d d d,(15.4,9.8,6.3)$ \\
\hline & 5 & 177.3 & $\mathrm{C}$ & & 177.1 & $\mathrm{C}$ & \\
\hline & $\mathrm{NH}$ & & & $8.00, d,(5.6)$ & & & $7.99, d,(4.9)$ \\
\hline & 5- $\mathrm{NH}_{2}$ & & & $6.77, b r s$ & & & $6.77, b r s$ \\
\hline & & & & 7.44, brs & & & $7.45, b r s$ \\
\hline \multirow[t]{5}{*}{$\mathrm{Aib}^{8}$} & 1 & 178.2 & $\mathrm{C}$ & & 178.2 & $\mathrm{C}$ & \\
\hline & 2 & 57.6 & $\mathrm{C}$ & & 57.6 & $\mathrm{C}$ & \\
\hline & 3 & 23.3 & $\mathrm{CH}_{3}$ & $1.52, s$ & 23.3 & $\mathrm{CH}_{3}$ & $1.52, s$ \\
\hline & 4 & 27.4 & $\mathrm{CH}_{3}$ & $1.55, s$ & 27.4 & $\mathrm{CH}_{3}$ & $1.55, s$ \\
\hline & $\mathrm{NH}$ & & & $8.09, \mathrm{~s}$ & & & $8.08, \mathrm{~s}$ \\
\hline \multirow[t]{6}{*}{$\mathrm{Val}^{9}$} & 1 & 175.3 & $\mathrm{C}$ & & 175.3 & $\mathrm{C}$ & \\
\hline & 2 & 65.7 & $\mathrm{CH}$ & $3.58, d d,(9.8,3.5)$ & 65.7 & $\mathrm{CH}$ & $3.58, d d,(9.3,3.2)$ \\
\hline & 3 & 30.4 & $\mathrm{CH}$ & $2.25, m$ & 30.6 & $\mathrm{CH}$ & $2.25, m$ \\
\hline & 4 & 19.6 & $\mathrm{CH}_{3}$ & $1.00, d,(6.3)$ & 19.6 & $\mathrm{CH}_{3}$ & $1.00, d,(6.4)$ \\
\hline & 5 & 20.8 & $\mathrm{CH}_{3}$ & $1.13, d,(6.3)$ & 20.8 & $\mathrm{CH}_{3}$ & $1.13, d,(6.3)$ \\
\hline & $\mathrm{NH}$ & & & $7.49, d,(4.9)$ & & & $7.49, d,(4.9)$ \\
\hline \multirow[t]{5}{*}{$\mathrm{Aib}^{10}$} & 1 & 179.0 & $\mathrm{C}$ & & 179.0 & $\mathrm{C}$ & \\
\hline & 2 & 57.6 & $\mathrm{C}$ & & 57.6 & $\mathrm{C}$ & \\
\hline & 3 & 26.8 & $\mathrm{CH}_{3}$ & $1.54, s$ & 26.8 & $\mathrm{CH}_{3}$ & $1.54, s$ \\
\hline & 4 & 27.1 & $\mathrm{CH}_{3}$ & $1.56, s$ & 27.1 & $\mathrm{CH}_{3}$ & $1.56, s$ \\
\hline & $\mathrm{NH}$ & & & $8.22, s$ & & & $8.22, s$ \\
\hline
\end{tabular}




\section{Table 1. continued}

\begin{tabular}{|c|c|c|c|c|c|c|c|}
\hline \multirow[b]{2}{*}{ residue } & \multirow[b]{2}{*}{ position } & \multicolumn{3}{|c|}{2} & \multicolumn{3}{|c|}{3} \\
\hline & & $\delta_{\mathrm{C}}$ & type & $\delta_{\mathrm{H}}, \mathrm{m}(J$ in $\mathrm{Hz})$ & $\delta_{\mathrm{C}}$ & type & $\delta_{\mathrm{H}}, \mathrm{m}(J$ in $\mathrm{Hz})$ \\
\hline \multirow[t]{4}{*}{ Gly $^{11}$} & 1 & 173.0 & $\mathrm{C}$ & & 173.0 & $\mathrm{C}$ & \\
\hline & 2 & 45.1 & $\mathrm{CH}_{2}$ & 3.67, $m$ & 45.0 & $\mathrm{CH}_{2}$ & $3.67, d d(16.8,5.6)$ \\
\hline & & & & $3.94, m$ & & & $3.95, \mathrm{~m}$ \\
\hline & $\mathrm{NH}$ & & & 8.34, brt, (5.6) & & & $8.34, b r t,(5.7)$ \\
\hline \multirow[t]{8}{*}{$\mathrm{Leu}^{12}$} & 1 & 175.8 & $\mathrm{C}$ & & 175.8 & $\mathrm{C}$ & \\
\hline & 2 & 54.1 & $\mathrm{CH}$ & $4.46, m$ & 54.0 & $\mathrm{CH}$ & $4.45, m$ \\
\hline & 3 & 41.5 & $\mathrm{CH}_{2}$ & 1.59 , overlapped & 41.5 & $\mathrm{CH}_{2}$ & 1.59 , overlapped \\
\hline & & & & $1.96, m$ & & & $1.96, m$ \\
\hline & 4 & 25.6 & $\mathrm{CH}$ & $1.91, m$ & 25.6 & $\mathrm{CH}$ & $1.91, m$ \\
\hline & 5 & 21.3 & $\mathrm{CH}_{3}$ & $0.92, d,(6.3)$ & 21.3 & $\mathrm{CH}_{3}$ & $0.92, d,(6.3)$ \\
\hline & 6 & 23.4 & $\mathrm{CH}_{3}$ & $0.94, d,(6.3)$ & 23.4 & $\mathrm{CH}_{3}$ & $0.94, d,(6.3)$ \\
\hline & $\mathrm{NH}$ & & & $8.11, d,(8.4)$ & & & $8.11, d,(7.8)$ \\
\hline \multirow[t]{5}{*}{$\mathrm{Aib}^{13}$} & 1 & 174.9 & $\mathrm{C}$ & & 174.9 & $\mathrm{C}$ & \\
\hline & 2 & 58.1 & $\mathrm{C}$ & & 58.1 & $\mathrm{C}$ & \\
\hline & 3 & 23.7 & $\mathrm{CH}_{3}$ & $1.61, s$ & 23.7 & $\mathrm{CH}_{3}$ & $1.61, s$ \\
\hline & 4 & 26.7 & $\mathrm{CH}_{3}$ & $1.54, s$ & 26.6 & $\mathrm{CH}_{3}$ & $1.54, s$ \\
\hline & $\mathrm{NH}$ & & & $8.40, s$ & & & $8.40, s$ \\
\hline \multirow[t]{8}{*}{$\operatorname{Pro}^{14}$} & 1 & 176.4 & $\mathrm{C}$ & & 176.4 & $\mathrm{C}$ & \\
\hline & 2 & 64.6 & $\mathrm{CH}_{2}$ & $4.38, d d,(9.1,6.3)$ & 64.6 & $\mathrm{CH}_{2}$ & $4.39, d d,(8.9,6.5)$ \\
\hline & 3 & 30.0 & $\mathrm{CH}_{2}$ & $1.80, m$ & 30.0 & $\mathrm{CH}_{2}$ & $1.80, m$ \\
\hline & & & & $2.35, m$ & & & $2.35, m$ \\
\hline & 4 & $26.9^{b}$ & $\mathrm{CH}_{2}$ & $1.99, m$ & $26.9^{b}$ & $\mathrm{CH}_{2}$ & $1.99, m$ \\
\hline & & & & $2.08, m$ & & & $2.08, m$ \\
\hline & 5 & 50.6 & $\mathrm{CH}_{2}$ & $3.73, m$ & 50.5 & $\mathrm{CH}_{2}$ & $3.73, m$ \\
\hline & & & & $3.88, d t,(11.2,6.3)$ & & & $3.88, d t,(11.9,6.2)$ \\
\hline \multirow[t]{6}{*}{$\mathrm{Val}^{15}$} & 1 & 175.3 & $\mathrm{C}$ & & 175.3 & $\mathrm{C}$ & \\
\hline & 2 & 64.3 & $\mathrm{CH}$ & $3.73, m$ & 64.3 & $\mathrm{CH}$ & $3.73, m$ \\
\hline & 3 & 30.5 & $\mathrm{CH}$ & $2.34, m$ & 30.5 & $\mathrm{CH}$ & $2.34, m$ \\
\hline & 4 & 19.4 & $\mathrm{CH}_{3}$ & $0.97, d,(6.3)$ & 19.4 & $\mathrm{CH}_{3}$ & $0.98, d,(6.5)$ \\
\hline & 5 & 20.2 & $\mathrm{CH}_{3}$ & $1.07, d,(6.3)$ & 20.2 & $\mathrm{CH}_{3}$ & $1.07, d,(6.4)$ \\
\hline & $\mathrm{NH}$ & & & $7.63, d$, overlapped & & & $7.63, d(8.0)$ \\
\hline \multirow[t]{5}{*}{$\mathrm{Aib}^{16}$} & 1 & 177.6 & $\mathrm{C}$ & & 177.6 & $\mathrm{C}$ & \\
\hline & 2 & 57.6 & $\mathrm{C}$ & & 57.6 & $\mathrm{C}$ & \\
\hline & 3 & 23.4 & $\mathrm{CH}_{3}$ & $1.54, s$ & 23.4 & $\mathrm{CH}_{3}$ & $1.54, s$ \\
\hline & 4 & 27.4 & $\mathrm{CH}_{3}$ & $1.54, s$ & 27.4 & $\mathrm{CH}_{3}$ & $1.54, s$ \\
\hline & $\mathrm{NH}$ & & & $7.58, s$ & & & $7.59, s$ \\
\hline \multirow[t]{5}{*}{$\mathrm{Aib}^{17}$} & 1 & 178.8 & $\mathrm{C}$ & & 178.8 & $\mathrm{C}$ & \\
\hline & 2 & 57.7 & $\mathrm{C}$ & & 57.7 & $\mathrm{C}$ & \\
\hline & 3 & 23.4 & $\mathrm{CH}_{3}$ & $1.53, \mathrm{~s}$ & 23.4 & $\mathrm{CH}_{3}$ & $1.53, \mathrm{~s}$ \\
\hline & 4 & 27.4 & $\mathrm{CH}_{3}$ & $1.55, \mathrm{~s}$ & 27.4 & $\mathrm{CH}_{3}$ & $1.55, \mathrm{~s}$ \\
\hline & NH & & & $7.81, s$ & & & $7.81, s$ \\
\hline \multirow[t]{9}{*}{$\mathrm{G} \ln ^{18}$} & 1 & 175.6 & $\mathrm{C}$ & & 175.5 & $\mathrm{C}$ & \\
\hline & 2 & 57.0 & $\mathrm{CH}$ & $4.01, m$ & 57.0 & $\mathrm{CH}$ & $4.01, m$ \\
\hline & 3 & 28.0 & $\mathrm{CH}_{2}$ & $2.25, m$ & 28.0 & $\mathrm{CH}_{2}$ & $2.25, m$ \\
\hline & 4 & 33.2 & $\mathrm{CH}_{2}$ & $2.43, d t,(15.4,8.4)$ & 33.1 & $\mathrm{CH}_{2}$ & $2.43, d t,(15.5,8.6)$ \\
\hline & & & & $2.62, d t,(15.4,7.7)$ & & & $2.62, d t,(15.2,8.0)$ \\
\hline & 5 & 177.4 & $\mathrm{C}$ & & 177.4 & $\mathrm{C}$ & \\
\hline & $\mathrm{NH}$ & & & $7.78, d,(5.6)$ & & & $7.79, d,(5.4)$ \\
\hline & $5-\mathrm{NH}_{2}$ & & & $6.78, b r s$ & & & 6.79, brs \\
\hline & & & & 7.44, brs & & & 7.45, brs \\
\hline \multirow[t]{9}{*}{$\mathrm{Gln}{ }^{19}$} & 1 & 174.1 & $\mathrm{C}$ & & 174.0 & $\mathrm{C}$ & \\
\hline & 2 & 55.7 & $\mathrm{CH}$ & $4.15, m$ & 55.6 & $\mathrm{CH}$ & $4.16, m$ \\
\hline & 3 & 27.9 & $\mathrm{CH}_{2}$ & $1.99, m$ & 27.9 & $\mathrm{CH}_{2}$ & $2.01-2.05, m$ \\
\hline & 4 & 32.9 & $\mathrm{CH}_{2}$ & $2.19, m$ & 32.9 & $\mathrm{CH}_{2}$ & $2.23, m$ \\
\hline & & & & $2.34, m$ & & & $2.34, m$ \\
\hline & 5 & 177.3 & $\mathrm{C}$ & & 177.3 & $\mathrm{C}$ & \\
\hline & $\mathrm{NH}$ & & & $7.86, d,(7.7)$ & & & $7.87, d,(7.5)$ \\
\hline & $5-\mathrm{NH}_{2}$ & & & $6.62, b r s$ & & & $6.63, b r s$ \\
\hline & & & & $7.35, b r s$ & & & $7.35, b r s$ \\
\hline
\end{tabular}




\section{Table 1. continued}

\begin{tabular}{|c|c|c|c|c|c|c|c|}
\hline \multirow[b]{2}{*}{ residue } & \multirow[b]{2}{*}{ position } & \multicolumn{3}{|c|}{2} & \multicolumn{3}{|c|}{3} \\
\hline & & $\delta_{\mathrm{C}}$ & type & $\delta_{\mathrm{H}}, \mathrm{m}(J$ in $\mathrm{Hz})$ & $\delta_{\mathrm{C}}$ & type & $\delta_{\mathrm{H}}, \mathrm{m}(\mathrm{J}$ in $\mathrm{Hz})$ \\
\hline \multirow[t]{13}{*}{ Pheol $^{20} /$ F-Pheol ${ }^{20}$} & 1 & 65.1 & $\mathrm{CH}_{2}$ & $3.65, b r t$ & 64.9 & $\mathrm{CH}_{2}$ & 3.63, brt \\
\hline & 2 & 52.9 & $\mathrm{CH}$ & $4.25, m$ & 54.0 & $\mathrm{CH}$ & $4.16, m$ \\
\hline & 3 & 31.1 & $\mathrm{CH}_{2}$ & $2.70, d d,(14.0,9.1)$ & 37.7 & $\mathrm{CH}_{2}$ & $2.72, d d,(14.2,9.7)$, \\
\hline & & & & $3.07, d d,(14.0,4.9)$ & & & $2.98, d d,(13.9,4.8)$ \\
\hline & 4 & $126.5, d,(15.4)$ & $\mathrm{C}$ & & $142.6, d,(7.4)$ & $\mathrm{C}$ & \\
\hline & 5 & $162.6, d,(242.7)$ & $\mathrm{CF}$ & & $117.1, d,(21.0)$ & $\mathrm{CH}$ & 7.06, brd, $(10.2)$ \\
\hline & 6 & $115.5, d,(22.1)$ & $\mathrm{CH}$ & $6.99, t,(9.1)$ & $160.0, d,(242.4)$ & $\mathrm{CF}$ & \\
\hline & 7 & $129.1, d,(8.4)$ & $\mathrm{CH}$ & $7.18, d d,(7.1,7.0)$ & $113.8, d,(21.0)$ & $\mathrm{CH}$ & $6.88, t d,(8.5,2.3)$ \\
\hline & 8 & $124.9, d,(3.7)$ & $\mathrm{CH}$ & $7.04, t,(7.7)$ & $130.7, d,(8.2)$ & $\mathrm{CH}$ & $7.24, t,(7.6)$ \\
\hline & 9 & $132.9, d,(4.4)$ & $\mathrm{CH}$ & $7.37, t,(7.7)$ & $126.3, d,(2.6)$ & $\mathrm{CH}$ & $7.10, d,(7.6)$ \\
\hline & $\mathrm{NH}$ & & & $7.32, d,(9.1)$ & & & $7.22, d$, overlapped \\
\hline & $1-\mathrm{OH}$ & & & $5.23, t,(6.6)$ & & & $5.27, t,(6.6)$ \\
\hline & $\mathrm{F}$ & & & $-119.7^{c}, m$ & & & $-115.8^{c}, m$ \\
\hline
\end{tabular}

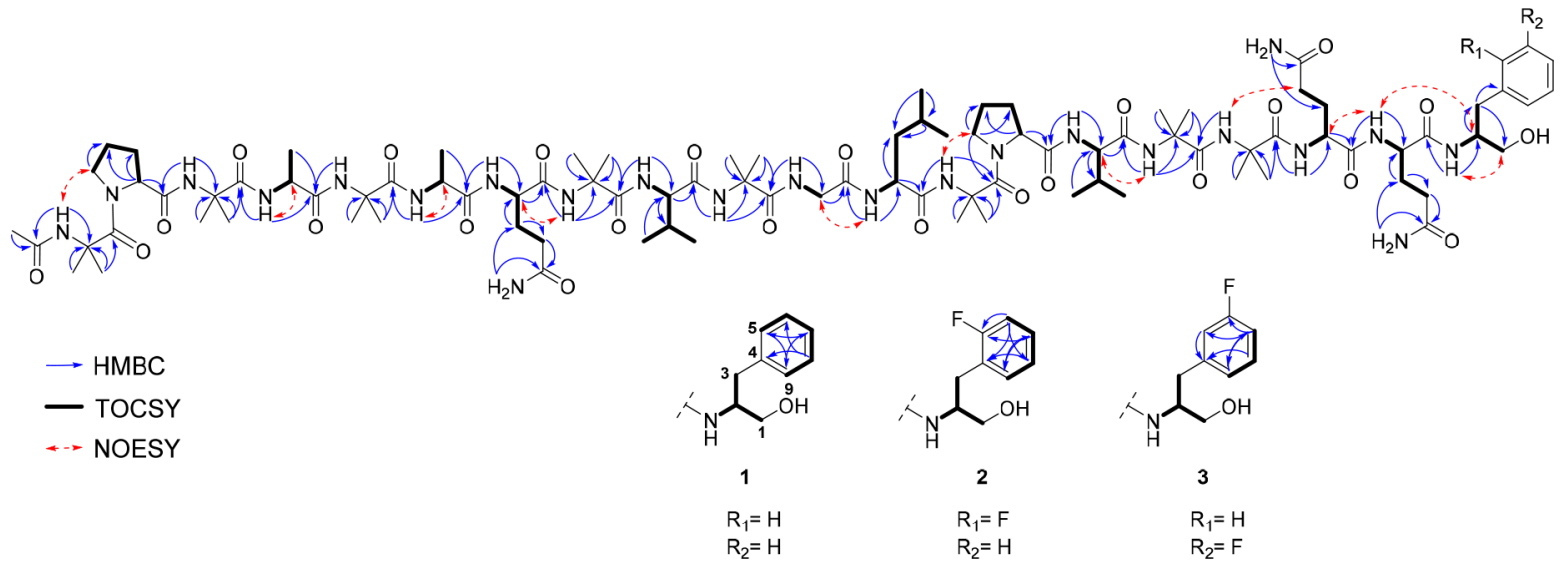

Figure 3. Key HMBC, TOCSY, and NOESY correlations for compounds 1-3.

alamethicin F50 (1; Figure 1) as the main constituent in an extract of fungal strain MSX70741 (Figure S1, Supporting Information), a Trichoderma isolate from the Mycosynthetix library. ${ }^{38}$ Compound 1 is a long-chain peptaibol (20 amino acid residues), which contains a high proportion of $\alpha$-aminoisobutyric acid (Aib, 8 residues), includes an acyl substituted $N$ terminus, and has a C-terminal phenylalaninol (Pheol) moiety. ${ }^{39-41}$ Taking into account this structural information, we selected the Pheol ${ }^{20}$ building block as an attractive target for the introduction of a fluorine atom into the alamethicin F50 molecule $(\mathbf{1})$ in a site-selective manner. We hypothesized that doing so would not drastically impact the biosynthesis of $\mathbf{1}$, and the resulting analogue should retain the $\alpha$-helical conformation, which is a key feature for the biological activity of peptaibols as membrane modifiers and pore-forming antibiotics. ${ }^{42}-44$ Therefore, in this communication we present the in vivo synthesis, as well as the isolation, structure elucidation, and biological evaluation of two new fluorinated-alamethicin F50 analogues, which were biosynthesized in wild type fungal species using the noncanonical amino acids ortho and meta F-substituted phenylalanine (Phe).

\section{RESULTS AND DISCUSSION}

Strain MSX70741 was identified as Trichoderma arundinaceum based on morphological and molecular characterization (Figures S2-S4). Cultures of this strain grown in potato dextrose agar (PDA) or PDA supplemented with a racemic mixture of either ortho-F-DL-Phe, meta-F-DL-Phe or para-F-DLPhe (500 ppm; see Figure S1 for photographs of the cultures) were monitored in situ using a droplet-liquid microjunctionsurface sampling probe (droplet-LMJ-SSP) coupled to a UPLC-PDA-HRMS-MS/MS system. ${ }^{45}$ All of these cultures showed characteristic in-source ion peaks for alamethicin F50 (1), such as $m / z 1963.1313\left([\mathrm{M}+\mathrm{H}]^{+}\right.$; monoisotopic precursor ion), $1189.6942\left(\mathrm{~b}_{13}{ }^{+}\right.$fragment $), 982.0722([\mathrm{M}+$ $\left.2 \mathrm{H}]^{2+}\right), 774.4505\left(\mathrm{y}_{7}^{+}\right.$fragment $)$, and $655.0505\left([\mathrm{M}+3 \mathrm{H}]^{3+}\right)$ (Figure 2)..$^{38}$ Moreover, in the culture supplemented with metaF-DL-Phe, the mass spectrum also showed a set of peaks shifted by $17.99 \mathrm{amu}\left([\mathrm{M}+\mathrm{H}]^{+}=1981.1241\right.$, and $\left.\mathrm{y}_{7}{ }^{+}=792.4409\right), 9.00$ amu $\left([\mathrm{M}+2 \mathrm{H}]^{2+}=991.0670\right)$, and $6.00 \mathrm{amu}\left([\mathrm{M}+3 \mathrm{H}]^{3+}=\right.$ $661.0471)$, indicating the incorporation of a fluorine atom $(\mathrm{F}=$ $18.9984 \mathrm{amu}$, exact mass) into alamethicin F50 (1) (Figures 1 and 2). Similar results were observed in the MS spectrum of cultures supplemented with ortho-F-DL-Phe (Figure 2). Importantly, incubating the microorganism with para-F-DLPhe did not result in the biosynthesis of the para-F-Pheol alamethicin F50 analogue (Figure 2), as previously reported for beauvericin, ${ }^{46}$ pseurotin and synerazol analogues, ${ }^{47}$ giving insights into the specificity in building block recognition by nonribosomal peptide synthetases (NRPS). ${ }^{48}$

To obtain enough material for structural characterization of the putative fluorinated alamethicin F50 analogues, $T$. arundinaceum strain MSX70741 was grown on rice and rice supplemented with each of the fluorinated building blocks 

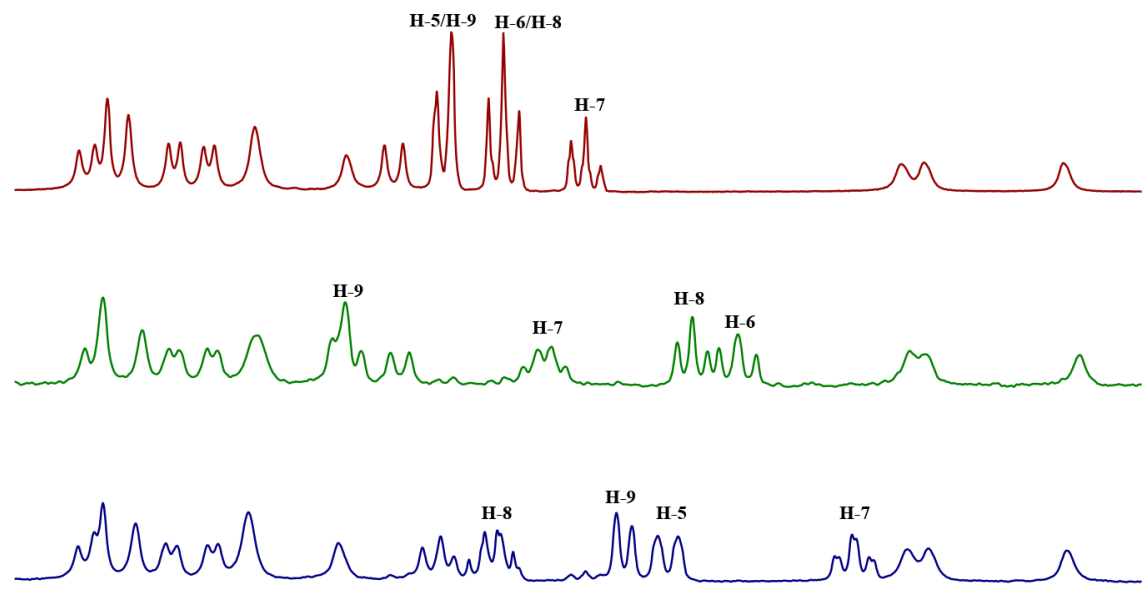

$\begin{array}{llllllllllllllllllllllll}7.70 & 7.65 & 7.60 & 7.55 & 7.50 & 7.45 & 7.40 & 7.35 & 7.30 & 7.25 & 7.20 & 7.15 & 7.10 & 7.05 & 7.00 & 6.95 & 6.90 & 6.85 & 6.80 & 6.75 & 6.70 & 6.65 & 6\end{array}$

Figure 4. Comparison of the ${ }^{1} \mathrm{H}$ NMR spectra in the aromatic region (6.60-7.65 ppm) for alamethicin F50 (1; maroon), ortho-F-Pheol alamethicin F50 (2; green), and meta-F-Pheol alamethicin F50 (3; navy). All spectra were recorded in $\mathrm{CD}_{3} \mathrm{OH}$ at $700 \mathrm{MHz}$. The spectra were identical from 0.75 to $6.50 \mathrm{ppm}$. For clarity, the signals belonging to the aromatic ring in each compound have been labeled and correspond to the data for the Pheol ${ }^{20}$ residues shown in Tables S3, S4, and S5 for compounds 1, 2, and 3, respectively.

(ortho/meta/para-F-DL-Phe), separately, following established procedures (Scheme S1). ${ }^{49-52}$ HRESIMS analysis of the extracts obtained after 21 days of fermentation confirmed the presence of alamethicin F50 (1), as well as its ortho and meta-FPheol analogues (Figure S11), and support the hypothesis of the inability of the microorganism's biosynthetic machinery to incorporate fluorine by assimilation of para-F-Phe. Purification of the organic extract $(1: 1 \mathrm{MeCN}-\mathrm{MeOH})$ of these cultures using a set of chromatographic procedures, and guided by MS analysis for the fluorinated signals, led to the isolation of two fluorinated peptaibols, namely, ortho-F-Pheol alamethicin F50 (2) and meta-F-Pheol alamethicin F50 (3), in ratios of 1:20 and 1:10 compared with the nonfluorinated parent (1).

Compounds 2 and 3 were isolated as white amorphous powders. Their molecular formulas were established as $\mathrm{C}_{92} \mathrm{H}_{150} \mathrm{FN}_{23} \mathrm{O}_{24}$ on the basis of the protonated molecule peaks $[\mathrm{M}+\mathrm{H}]^{+}$at $m / z 1981.1290$ and 1981.1294 for 2 and 3, respectively, in the HRESIMS spectrum (29 degrees of unsaturation). The incorporation of the fluorine atom into alamethicin F50 (1) was detected on the basis of the characteristic mass shifts of $[\mathrm{M}+\mathrm{H}]^{+},[\mathrm{M}+2 \mathrm{H}]^{2+},[\mathrm{M}+$ $3 \mathrm{H}]^{3+}$, and $\mathrm{y}_{7}{ }^{+}$ions (Figures S13, S21, and S31). The structures of 2 and 3 were confirmed by exhaustive interpretation of $1 \mathrm{D}$ and $2 \mathrm{D}$ NMR data, including ${ }^{19} \mathrm{~F}-\mathrm{NMR}$ spectra (Figures S30 and S40). The ${ }^{1} \mathrm{H}$ NMR (Table 1) spectra for 2 and 3 showed resonances for $18 \mathrm{NH}$ groups $\left(\delta_{\mathrm{H}} 6.50-8.70 \mathrm{ppm}\right)$, three $\mathrm{NH}_{2}$ $\left(\mathrm{Gln}{ }^{7}, \mathrm{Gln}^{18}\right.$, and $\left.\mathrm{Gln}^{19}\right)$, four aromatic protons among $\delta_{\mathrm{H}}$ $6.80-7.40 \mathrm{ppm}, 13 \alpha \mathrm{H}$ ranging $\delta_{\mathrm{H}} 3.30-4.50 \mathrm{ppm}$, one acetyl group at $\delta_{\mathrm{H}} 2.05 \mathrm{ppm}$, and several signals in the shielded region $\left(\delta_{\mathrm{H}} 0.70-2.50 \mathrm{ppm}\right)$, including 16 methyl singlets (Aib) and eight methyl doublets, confirming 2 and 3 to be peptaibol derivatives. $^{38,53,54}$ Analysis of the 2D NMR data, in particular COSY, TOCSY, and HMBC experiments (Figure 3), permitted the assignment of the side chain for each amino acid (eight Aib, three Gln, two Ala, two Val, two Pro, one Leu, one Gly, and one F-substituted Pheol moiety). On the other hand, ${ }^{3} J_{\mathrm{CH}}$ and ${ }^{2} J_{\mathrm{CH}} \mathrm{HMBC}$ correlations between $\mathrm{NH}$ protons and the $\alpha \mathrm{C}$ and $\mathrm{C}=\mathrm{O}$ signals, as well as the NOESY correlations among $\alpha \mathrm{H}$ and $\mathrm{NH}$ protons of the neighboring amino acids, supported the structures of 2 and 3 as the ortho-F-Pheol and meta-F-Pheol analogues of alamethicin F50 (1), respectively (Figure 3). In general, the ${ }^{1} \mathrm{H}$ and ${ }^{13} \mathrm{C}$ NMR spectra for compounds 2 and 3 were almost identical to those recorded for $\mathbf{1}$ (Table 1; Figure 4), the main differences being in the chemical shifts and splitting of signals attributed to an ortho and meta F-substituted phenyl ( 2 and 3 , respectively), equivalent to the phenylalaninol $\left(\mathrm{Pheol}^{20}\right.$ ) moiety in $\mathbf{1}$ (Figure 4, Table 1). Thus, in the ${ }^{13} \mathrm{C}$ NMR spectrum for 2 and 3 , a set of six doublets were displayed in the aromatic region $\left(\delta_{\mathrm{C}} 115-163 \mathrm{ppm}\right)$, instead of four singlet peaks observed for $1\left(\delta_{\mathrm{C}} 127-140 \mathrm{ppm}\right.$; Table 1$)$. The observation of splitting in a proton-decoupled ${ }^{13} \mathrm{C}$ NMR experiment confirmed the incorporation of the fluorinated building blocks into the products, as noted by the prominent $J_{\mathrm{FC}}$ values (Table 1). Importantly, the presence of a fluorine atom in $\mathbf{2}$ and $\mathbf{3}$ was verified by ${ }^{19} \mathrm{~F}$ NMR spectroscopy with $\delta_{\mathrm{F}}$ values of -119.7 and $-115.8 \mathrm{ppm}$ compared to $\delta_{\mathrm{F}}$ values of -119.7 and $-114.8 \mathrm{ppm}$ for the racemic mixtures of amino acids ortho-F-DL-Phe and meta-F-DL-Phe, respectively (Tables 1 and S2). The ${ }^{19} \mathrm{~F}-\mathrm{NMR}$ signals for products $\mathbf{2}$ and $\mathbf{3}$ had similar ${ }^{19} \mathrm{~F}-{ }^{1} \mathrm{H}$ coupling patterns to those observed for their corresponding building blocks, confirming their incorporation into alamethicin F50 (1) (Table S2).

The amino acid sequences in $\mathbf{2}$ and $\mathbf{3}$ were also examined by HRESIMS/MS (Figures S22 and S32). In the case of compound 3, the full scan HRESIMS spectra exhibited several common in-source ions, specifically $[\mathrm{M}+\mathrm{H}]^{+},[\mathrm{M}+2 \mathrm{H}]^{2+},[\mathrm{M}$ $+3 \mathrm{H}]^{3+}, \mathrm{b}_{13}{ }^{+}$and $\mathrm{y}_{7}{ }^{+}$fragments, with the latter two generated from the cleavage between $\mathrm{Aib}^{13}$ and Pro $^{14}$ (Figure S31). ${ }^{38}$ In compound 3, for example, fragmentation of the ion $b_{13}{ }^{+}$at $m / z$ 1189.69 gave peaks at $m / z$ 934.5372, 849.4816, 750.4141, $665.3605,537.3030,466.2657,381.2129,310.1757$, and 225.1231 indicating the successive losses of $\mathrm{Aib}^{13}-\mathrm{Leu}^{12}-\mathrm{Gly}^{11}$, $\mathrm{Aib}^{10}, \mathrm{Val}^{9}, \mathrm{Aib}^{8}, \mathrm{Gln}^{7}, \mathrm{Ala}^{6}, \mathrm{Aib}^{5}, \mathrm{Ala}^{4}$, and $\mathrm{Aib}^{3}$ and supporting the sequence $A c A i b^{1}-\mathrm{Pro}^{2}-\mathrm{Aib}^{3}-\mathrm{Ala}^{4}-\mathrm{Aib}^{5}-\mathrm{Ala}^{6}-\mathrm{Gln}^{7}-\mathrm{Aib}^{8}-\mathrm{Val}^{9}$ $\mathrm{Aib}^{10}-\mathrm{Gly}^{11}-\mathrm{Leu}^{12}-\mathrm{Aib}^{13}$. Similar fragmentation of the $[\mathrm{M}+$ $2 \mathrm{H}]^{2+}$ ion, in particular the fragment $\mathrm{y}_{7}^{+}$permitted the assignment of the C-terminal fragment as $\mathrm{Pro}^{14}-\mathrm{Val}^{15}-\mathrm{Aib}^{16}$ $\mathrm{Aib}^{17}-\mathrm{Gln}^{18}-\mathrm{Gln}^{19}$-(meta-F)Pheol ${ }^{20}$. Analogous mass spectrometric experiments were used to assign the amino acid sequence in 2 (Figures S21 and S22). 
The absolute configuration of each amino acid in $\mathbf{2}$ and $\mathbf{3}$ was confirmed by acid hydrolysis, Marfey's derivatization under alkaline conditions, and analysis of the derivatives using a 10 min UPLC protocol. ${ }^{38}$ For this, the appropriate standards for the $\mathrm{D}$ and $\mathrm{L}$ enantiomers of the ortho and meta F-Pheol building blocks were prepared (Supporting Information). ${ }^{55}$ As expected, the absolute configuration of all amino acids in $\mathbf{2}$ and $\mathbf{3}$ was $\mathrm{L}$, as previously reported for alamethicin F50 (1) by Ayers et al. ${ }^{38}$ Importantly, these results indicated that $T$. arundinaceum strain MSX70741 incorporated only the L-enantiomer of the fluorinated building blocks into the alamethicin F50 analogues $(2,3)$ (Figures S9 and S10). In previous studies, the absolute configurations of the fluorinated analogues of beauvericin, pseurotin, and synerazol were presumed to be the same as in the parent compounds, based on the detection of one diastereomer and specific rotation data. ${ }^{46,47}$

To assess the bioactivities of compounds 2 and 3 , their $\mathrm{IC}_{50}$ values were determined against a panel of cancer cell lines [MDA-MB-435 (melanoma), MDA-MB-231 (adenocarcinoma), and OVCAR3 (ovarian cancer)], ${ }^{51,52,56-58}$ In these cytotoxicity assays, compounds 2 and 3 were equipotent to their nonfluorinated parent, with $\mathrm{IC}_{50}$ values ranging from 4.8 to $6.4 \mu \mathrm{M}$ (Table 2). These data suggested that the incorporation of fluorine into the alamethicin F50 (1) molecule did not drastically impact the cytotoxicity of the compounds.

Table 2. Bioactivity Data of Compounds 1-6

\begin{tabular}{cccc} 
& \multicolumn{3}{c}{$\mathrm{IC}_{50}(\mu \mathrm{M})^{a}$} \\
\cline { 2 - 4 } compd & MDA-MB-435 & MDA-MB-231 & OVCAR3 \\
$\mathbf{1}$ & 4.9 & 5.6 & 1.5 \\
$\mathbf{2}$ & 6.4 & 5.9 & 4.8 \\
$\mathbf{4}$ & 4.8 & 5.9 & 6.3 \\
$\mathbf{5}$ & 4.8 & 5.1 & 5.1 \\
$\mathbf{6}$ & 4.7 & 5.0 & 5.0 \\
Paclitaxel (taxol) & 2.8 & 4.3 & 4.4 \\
& 0.0005 & 0.009 & 0.002
\end{tabular}

${ }^{a} \mathrm{IC}_{50}$ values were determined as the concentration required to reduce cellular proliferation by $50 \%$ relative to the untreated controls following $72 \mathrm{~h}$ of continuous exposure.

In an attempt to stimulate the fungus to increase the biosynthesis of the fluorinated analogues of alamethicin F50, an experiment was designed as follows: $T$. arundinaceum was cultured on PDA for 3 days. Subsequently, an agar plug with mycelium from the leading edge of the colony was used to inoculate $10 \mathrm{~mL}$ of liquid medium containing $2 \%$ of soy peptone, $2 \%$ dextrose, and $1 \%$ yeast extract (YESD). After 3 days of growth, the liquid media was used to inoculate either autoclaved rice $\left(10 \mathrm{~g}\right.$ of rice and $20 \mathrm{~mL}$ of $\mathrm{H}_{2} \mathrm{O}$; control), or autoclaved rice containing either: (1) $130 \mathrm{mg}$ (powder) of ortho-F-DL-Phe; (2) $37.5 \mathrm{mg}$ of ortho-F-DL-Phe in $5.0 \mathrm{~mL}$ of $\mathrm{H}_{2} \mathrm{O}$ (final concentration: $1250 \mathrm{ppm}$ ); (3) $15 \mathrm{mg}$ of ortho-F-DLPhe in $2.0 \mathrm{~mL}$ of $\mathrm{H}_{2} \mathrm{O}$ (final concentration: $500 \mathrm{ppm}$ ); or (4) $15 \mathrm{mg}$ of ortho-F-L-Phe in $2.0 \mathrm{~mL}$ of $\mathrm{H}_{2} \mathrm{O}$ (final concentration: $500 \mathrm{ppm}$ ) (Scheme S2). All four cultures were incubated for 21 days and then extracted and analyzed by UPLC-PDA-MS. The fluorinated analogues were detected in all cultures. Subsequent isolation of compound 2 by HPLC-PDA-MS following the protocol described in the experimental section indicated that (1) supplementing the microorganism with $130 \mathrm{mg}$ of ortho-FDL-Phe increased the ratio of compounds $2 / 1$ to $1: 1$, although the overall yield of product declined significantly $(1 \mathrm{mg})$, and
(2) the optimum way to obtain the ortho fluorinated analogues of alamethicin F50 was supplementing the media with $500 \mathrm{ppm}$ of ortho-F-DL-Phe, yielding $11.4 \mathrm{mg}$ of a $2: 5$ ratio of $2 / 1$.

Finally, to validate the protocol used for biosynthesis of peptaibols fluorinated in the Pheol moiety at the C-terminal, we selected Trichoderma albolutescens strain MSX57715 (details about the strain identification are provided in the Supporting Information, Figure S5), which biosynthesizes the peptaibol trichokonin VI (4). ${ }^{38}$ Cultivation of this strain under the same conditions used for strain MSX70741 led to the isolation of the ortho and meta-F-Pheol analogues of trichokonin VI (4-6, Figure 1). As observed with MSX70741, MSX57715 incorporated only the ortho and meta-F-L-Phe building blocks into trichokonin VI (4), and not the para substituted analogue. From the point of view of bioactivity, compounds 5 and 6 displayed potency similar to the nonfluorinated parent when evaluated against the same panel of cancer cell lines, with $\mathrm{IC}_{50}$ values in the lower $\mu \mathrm{M}$ range (Table 2 ).

As demonstrated in this study, a site-directed building block incorporation approach can be a powerful tool for studying, and perhaps expanding upon, the chemical diversity available through nature. Primarily, this approach facilitates the incorporation of fragments that are rarely found in nature into complex secondary metabolites. Second, these unnatural metabolites, which may be otherwise difficult to obtain, contribute to the expansion of chemical space around privileged scaffolds. ${ }^{59}$ Moreover, these new biosynthetic products may address some perceived challenges to the screening of natural products, ${ }^{60}$ such as legal access to biodiversity, identification of biological activity, and most recently, intellectual property associated with composition of matter patents, ${ }^{60,61}$ which many would consider the most desirable of "Orange Book" patents. ${ }^{62}$ In short, this approach imparts another way to translate natural products discoveries into further development. In particular, this methodology opens up new avenues for targeting the biosynthesis of bioactive compounds (i.e., privileged scaffolds) with potentially improved physicochemical and pharmacological properties. This technique, in combination with appropriate genomic approaches, ${ }^{8}$ may lead to the generation of valuable compounds.

In summary, we report the biosynthesis of fluorine containing analogues of the peptaibols alamethicin F50 (2,3) and trichokonin VI $(\mathbf{5 , 6 )}$ using a site-directed building block incorporation approach. Importantly, the biosynthesis of these products was carried out using wild type Trichoderma strains. Biosynthesis of products 2, 3, 5, and 6 represent the first report of the application of a site-directed building block incorporation approach targeting the incorporation of a fluorine atom into peptaibol type molecules. Notably, examination of the ability of Trichoderma species to incorporate the fluorinated building blocks was monitored in situ, facilitating the identification of the products in an early stage of the study, before the scaling up of the cultures.

\section{EXPERIMENTAL SECTION}

General Experimental Procedures. NMR experiments were conducted in $\mathrm{CD}_{3} \mathrm{OH}$ with presaturation of the $\mathrm{OH}$ peak at $\delta_{\mathrm{H}} 4.92$ ppm (wet experiment). NMR instrumentation was a JEOL ECA-500 NMR spectrometer operating at $500 \mathrm{MHz}$ for ${ }^{1} \mathrm{H}, 470 \mathrm{MHz}$ for ${ }^{19} \mathrm{~F}$, and $125 \mathrm{MHz}$ for ${ }^{13} \mathrm{C}$, or an Agilent $700 \mathrm{MHz}$ NMR spectrometer equipped with a cryoprobe, operating at $700 \mathrm{MHz}$ for ${ }^{1} \mathrm{H}$ and 175 $\mathrm{MHz}$ for ${ }^{13} \mathrm{C}$. All chemical shifts were referenced to the residual solvent peaks $\left(\delta_{\mathrm{H}} 3.31\right.$ and $\left.\delta_{\mathrm{C}} 49.0\right)$. HRESIMS data were obtained using a Thermo QExactive Plus mass spectrometer (ThermoFisher 
Scientific) paired with an electrospray ionization source. Monitoring the biosynthesis of secondary metabolites in fungal cultures in situ was performed using the droplet-LMJ-SSP coupled with a Waters Acquity ultraperformance liquid chromatography (UPLC) system (Waters Corp.) to a Thermo QExactive Plus via procedures described previously by Sica et al. $^{45}$ Briefly, extractions were performed using Fisher Optima LC/MS grade solvents consisting of 50:50 MeOH$\mathrm{H}_{2} \mathrm{O}$. An initial $5 \mu \mathrm{L}$ of solvent was drawn into the syringe. Droplets of $4 \mu \mathrm{L}$ were dispensed onto the surface of the sample at a rate of $2 \mu \mathrm{L} / \mathrm{s}$, held on the surface for $2 \mathrm{~s}$, and withdrawn back into the syringe at the same rate. This extraction process was repeated in triplicate for a single spot prior to injection into the UPLC-MS system. The higher-energy collisional dissociation (HCD) used a normalized energy of 35 for all the compounds to obtain MS/MS data. The UPLC separations were performed using an Acquity BEH C18 column $(50 \mathrm{~mm} \times 2.1 \mathrm{~mm}$, internal diameter, $1.7 \mu \mathrm{m}$ ) equilibrated at $40{ }^{\circ} \mathrm{C}$ and a flow rate set at $0.3 \mathrm{~mL} / \mathrm{min}$. The mobile phase consisted of a linear $\mathrm{MeCN}-\mathrm{H}_{2} \mathrm{O}$ (acidified with $0.1 \%$ formic acid) gradient starting at $15 \% \mathrm{MeCN}$ to $100 \% \mathrm{MeCN}$ over $8 \mathrm{~min}$. The mobile phase was held for another 1.5 $\min$ at $100 \% \mathrm{MeCN}$ before returning to the starting conditions. The HPLC separations were performed using a Varian ProStar HPLC system connected to a ProStar 335 photodiode array detector (PDA) with UV detection set at 195 and $210 \mathrm{~nm}$. Preparative HPLC purifications of isolated compounds were performed on a Phenomenex Synergi $4 \mu \mathrm{m}$ particle size $\mathrm{C}_{12}$ column $(21 \times 250 \mathrm{~mm})$ at a flow rate of $20.0 \mathrm{~mL} / \mathrm{min}$. Flash column chromatography was carried out with a Teledyne ISCO Combiflash Rf connected to ELSD and PDA detectors, with the latter having UV detection set at $200-400 \mathrm{~nm}$, all according to established protocols. ${ }^{51,58,63,64}$ All solvents were obtained from Fisher Scientific and used without further purification. The $o / m / p$-F-DL-Phe, $o / m$-F-D-Phe, and $o / m$-F-L-Phe were purchased from Acros Organics. The standards of $o / m$-F-D-Pheol and $o / m$-F-LPheol were prepared as detailed in the Supporting Information.

Fungal Strain Isolation and Identification. Mycosynthetix fungal strain MSX70741 was isolated from wood collected in a humid mountain forest (April 1993), whereas strain MSX57715 was isolated from leaf litter in a predominately oak forest (October 1991) both by Dr. Barry Katz. ${ }^{38}$ Both strains were used previously for the isolation of peptaibols. ${ }^{38} \mathrm{~A}$ description of the procedures used to identify these strains was outlined recently, ${ }^{65}$ and the specific details are also provided in the Supporting Information (Table S1, Figures S2-S5). MSX70741 was identified as Trichoderma arundinaceum, whereas strain MSX57715 was identified as T. albolutescens. The sequence data for both strains were deposited in GenBank (accession numbers: ITS: KY630171, tef1: KY630169, KY630170, RPB2: KY630166 for strain MSX70741 and accession numbers: tef1: KY630167, KY630168, RPB2: KY630164, KY630165 for strain MSX57715).

Fermentation, Extraction, and Isolation. Fungal strains MSX70741 and MSX57715 were each grown on a malt extract agar, and subsequently, a small piece from the leading edge of the colony was transferred into YESD media (followed by incubation for 7 days at $22{ }^{\circ} \mathrm{C}$ with agitation at $125 \mathrm{rpm}$ ). The seed cultures were transferred into $250 \mathrm{~mL}$ Erlenmeyer flasks containing $50 \mathrm{~mL}$ of rice, which was prepared by adding a vitamin solution and twice the volume of rice with $\mathrm{H}_{2} \mathrm{O}$. These flasks were incubated at $22{ }^{\circ} \mathrm{C}$ until the culture showed good growth. In the case of media supplemented with a racemic mixture of ortho-F-DL-Phe (E2), meta-F-DL-Phe (E3), or paraF-DL-Phe (E4), $100 \mathrm{mg}$ of the amino acid were added to the culture after a week of growth (Scheme S1).

To each solid fermentation culture of MSX70741 (EC, E2-E4; see Scheme S1), $60 \mathrm{~mL}$ of $1: 1 \mathrm{MeOH}-\mathrm{CHCl}_{3}$ were added, and the resulting slurry was shaken for $16 \mathrm{~h}$ on an orbital shaker. These mixtures were filtered under vacuum. To each filtrate $90 \mathrm{~mL}$ of $\mathrm{CHCl}_{3}$ and $150 \mathrm{~mL}$ of $\mathrm{H}_{2} \mathrm{O}$ were added, and the mixtures were stirred for 30 min and then transferred into a separatory funnel. The organic layer was drawn off and dried in vacuo. This dried organic extract was defatted by reconstituting in a mixture of $100 \mathrm{~mL}$ of $1: 1 \mathrm{MeOH}-$ $\mathrm{MeCN}$ and $100 \mathrm{~mL}$ of hexane, and then partitioned in a separatory funnel. The $\mathrm{MeOH}-\mathrm{MeCN}$ layer was collected and concentrated in vacuo. The resulting $\mathrm{MeOH}-\mathrm{MeCN}$ extracts were then adsorbed on Celite 545 (Acros Organics) and fractionated via flash chromatography on a $4 \mathrm{~g}$ RediSep $\mathrm{Rf}$ Gold Si-gel column using a gradient solvent system of hexane- $\mathrm{CHCl}_{3}-\mathrm{MeOH}$ at a flow rate of $18 \mathrm{~mL} / \mathrm{min}$ over 90 column volumes $(\mathrm{CV})$ for a duration of $24.0 \mathrm{~min}$. Fractions were collected every $9.0 \mathrm{~mL}$ and pooled according to the UV and ELSD profiles, which resulted in four combined fractions in total $\left(\mathrm{F}_{\mathrm{I}}-\mathrm{F}_{\mathrm{IV}}\right)$. MS-directed resolution of fraction $\mathrm{F}_{\mathrm{IV}}$ from E2 and E3 (eluted with $100 \% \mathrm{MeOH}, 92.4$ and $136.0 \mathrm{mg}$, respectively) via reversed-phase HPLC (Synergi column), using a linear gradient from $40 \%$ to $100 \%$ $\mathrm{MeCN}$ in $\mathrm{H}_{2} \mathrm{O}$ (0.1\% formic acid) at a flow rate of $20.0 \mathrm{~mL} / \mathrm{min}$ over 30 min afforded seven subfractions $\left(\mathrm{F}_{\mathrm{IV}-1}-\mathrm{F}_{\mathrm{IV}-7}\right)$. Fractions $\mathrm{F}_{\mathrm{IV}-1}\left(t_{\mathrm{R}}\right.$ 18.5-19.5 $\mathrm{min}$ ) from E2 and E3 were further characterized as alamethicin F50 (1, 28.5 and $42.9 \mathrm{mg}$, respectively). Purification of fractions $\mathrm{F}_{\mathrm{IV}-2}$ from E2 and E3 by MS-directed semipreparative HPLC using the above-mentioned conditions at $4.60 \mathrm{~mL} / \mathrm{min}$ led to the isolation of compounds $2(1.4 \mathrm{mg})$ and $3(4.5 \mathrm{mg})$. Analogous procedures were used to isolate compounds $4(24.0 \mathrm{mg}), 5(3.4 \mathrm{mg})$, and $6(6.2 \mathrm{mg})$

Alamethicin F50 (1). White powder; $[\alpha]_{\mathrm{D}}^{26}-6.5(c 0.2, \mathrm{MeOH})$; $\mathrm{UV}(\mathrm{MeOH}) \lambda_{\max }(\log \varepsilon) 204(4.52) \mathrm{nm} ;{ }^{1} \mathrm{H}$ NMR $\left(\mathrm{CD}_{3} \mathrm{OH}, 700\right.$ $\mathrm{MHz})$ and ${ }^{13} \mathrm{C}$ NMR $\left(\mathrm{CD}_{3} \mathrm{OH}, 175 \mathrm{MHz}\right)$, see Table S3; HRESIMS $m / z 1963.1388[\mathrm{M}+\mathrm{H}]^{+}\left(\right.$calcd for $\mathrm{C}_{92} \mathrm{H}_{152} \mathrm{~N}_{23} \mathrm{O}_{24}, \mathrm{~m} / z$ 1963.1375)

o-F-Pheol-Alamethicin F50 (2). White powder; $[\alpha]_{\mathrm{D}}{ }^{26}-7.0$ (c 0.2 , $\mathrm{MeOH}) ; \mathrm{UV}(\mathrm{MeOH}) \lambda_{\max }(\log \varepsilon) 204$ (4.54) nm; ${ }^{1} \mathrm{H}$ NMR $\left(\mathrm{CD}_{3} \mathrm{OH}, 700 \mathrm{MHz}\right)$ and ${ }^{13} \mathrm{C} \mathrm{NMR}\left(\mathrm{CD}_{3} \mathrm{OH}, 175 \mathrm{MHz}\right)$, see Table 1; HRESIMS $m / z 1981.1290[\mathrm{M}+\mathrm{H}]^{+}$(calcd for $\mathrm{C}_{92} \mathrm{H}_{151} \mathrm{FN}_{23} \mathrm{O}_{24}$, 1981.1280)

m-F-Pheol-Alamethicin F50 (3). White powder; $[\alpha]_{\mathrm{D}}{ }^{27}-1.0(c$ $0.03, \mathrm{MeOH}) ; \mathrm{UV}(\mathrm{MeOH}) \lambda_{\max }(\log \varepsilon) 204(4.52) \mathrm{nm} ;{ }^{1} \mathrm{H}$ NMR $\left(\mathrm{CD}_{3} \mathrm{OH}, 700 \mathrm{MHz}\right)$ and ${ }^{13} \mathrm{C} \mathrm{NMR}\left(\mathrm{CD}_{3} \mathrm{OH}, 175 \mathrm{MHz}\right)$, see Table 1; HRESIMS $m / z 1981.1294[\mathrm{M}+\mathrm{H}]^{+}\left(\right.$calcd for $\mathrm{C}_{92} \mathrm{H}_{151} \mathrm{FN}_{23} \mathrm{O}_{24}$, 1981.1280).

Trichokonin VI (4). White powder; $[\alpha]_{\mathrm{D}}{ }^{24}-10.0(c 0.2, \mathrm{MeOH})$; $\mathrm{UV}(\mathrm{MeOH}) \lambda_{\max }(\log \varepsilon) 204$ (4.57) nm; HRESIMS $m / z 1937.1232$ $[\mathrm{M}+\mathrm{H}]^{+}$(calcd for $\left.\mathrm{C}_{90} \mathrm{H}_{150} \mathrm{~N}_{23} \mathrm{O}_{24}, 1937.1218\right)$.

o-F-Pheol-Trichokonin VI (5). White powder; $[\alpha]_{\mathrm{D}}{ }^{25}-8.0$ (c 0.3 , $\mathrm{MeOH})$; UV (MeOH) $\lambda_{\max }(\log \varepsilon) 204(4.54) \mathrm{nm}$; HRESIMS $\mathrm{m} / z$ $1955.1147[\mathrm{M}+\mathrm{H}]^{+}$(calcd for $\left.\mathrm{C}_{90} \mathrm{H}_{149} \mathrm{FN}_{23} \mathrm{O}_{24}, 1955.1124\right)$.

m-F-Pheol-Trichokonin VI (6). White powder; $[\alpha]_{\mathrm{D}}{ }^{25}-5.0$ (c 0.2, $\mathrm{MeOH}) ; \mathrm{UV}(\mathrm{MeOH}) \lambda_{\max }(\log \varepsilon) 204$ (4.48) nm; HRESIMS $m / z$ $1955.1149[\mathrm{M}+\mathrm{H}]^{+}\left(\right.$calcd for $\left.\mathrm{C}_{90} \mathrm{H}_{149} \mathrm{FN}_{23} \mathrm{O}_{24}, 1955.1124\right)$.

Cytotoxicity Assay. Human melanoma cancer cells MDA-MB435, human breast cancer cells MDA-MB-231, and human ovarian cancer cells OVCAR3 were purchased from the American Type Culture Collection (Manassas, VA, U.S.A.). The cell lines were propagated at $37{ }^{\circ} \mathrm{C}$ in $5 \% \mathrm{CO}_{2}$ in RPMI 1640 medium, supplemented with fetal bovine serum (10\%), penicillin (100 units $/ \mathrm{mL}$ ), and streptomycin $(100 \mu \mathrm{g} / \mathrm{mL})$. Cells in log phase of growth were harvested by trypsinization followed by two washes to remove all traces of enzyme. A total of 5000 cells were seeded per well of a 96well clear, flat-bottom plate (Microtest 96, Falcon) and incubated overnight $\left(37^{\circ} \mathrm{C}\right.$ in $\left.5 \% \mathrm{CO}_{2}\right)$. Samples dissolved in DMSO were then diluted and added to the appropriate wells (several concentrations; total volume: $100 \mu \mathrm{L}$; DMSO: $0.5 \%$ ). The cells were incubated in the presence of test substance for $72 \mathrm{~h}$ at $37^{\circ} \mathrm{C}$ and evaluated for viability with a commercial absorbance assay (CellTiter $96 \mathrm{AQ}_{\text {ueous }}$ One Solution Cell Proliferation Assay, Promega Corp, Madison) that measured viable cells. IC $_{50}$ values were determined as the concentration required to reduce cellular proliferation by $50 \%$ relative to the untreated controls following $72 \mathrm{~h}$ of continuous exposure. Paclitaxel (taxol) was used as a positive control.

Optimization of Biosynthesis of Fluorinated Analogues. For each different condition (Scheme S2) a seed of the fungal strain MSX70741 was grown on liquid YESD followed by incubation for 3 days at $22{ }^{\circ} \mathrm{C}$ with agitation at $125 \mathrm{rpm}$. The seed culture was transferred into $250 \mathrm{~mL}$ Erlenmeyer flasks containing $30 \mathrm{~mL}$ of rice medium, prepared using $10 \mathrm{~g}$ of rice and twice the volume of rice with $\mathrm{H}_{2} \mathrm{O}$. These flasks were supplemented with $130 \mathrm{mg}$ of ortho-F-DL-Phe powder (Condition 1), $2.0 \mathrm{~mL}$ of a stock solution $7500 \mathrm{ppm}$ of ortho- 
F-DL-Phe (500 ppm, Condition 2), $5.0 \mathrm{~mL}$ of a stock solution 7500 ppm of ortho-F-DL-Phe (1250 ppm, Condition 3), or $2.0 \mathrm{~mL}$ of a stock solution $7500 \mathrm{ppm}$ of ortho-F-L-Phe (500 ppm, Condition 4) (Scheme S2). The flasks were incubated at $22{ }^{\circ} \mathrm{C}$ until they showed good growth and then extracted according to the procedure mentioned in the fermentation, extraction, and isolation section.

Marfey's Analysis. Approximately $0.2 \mathrm{mg}$ of each amino acid standard was weighed into separate glass $2 \mathrm{~mL}$ reaction vials. To each standard was added $50 \mu \mathrm{L}$ of $\mathrm{H}_{2} \mathrm{O}, 20 \mu \mathrm{L}$ of $1 \mathrm{M} \mathrm{NaHCO}_{3}$, and 100 $\mu \mathrm{L} 1 \%$ Marfey's reagent ( $N \alpha$-(2,4-dinitro-5-fluorophenyl)-L-alaninamide) in acetone. The reaction mixtures were agitated at $40^{\circ} \mathrm{C}$ for $1 \mathrm{~h}$. The reactions were halted by the addition of $10 \mu \mathrm{L}$ of $2 \mathrm{~N} \mathrm{HCl}$. The product of the reactions was dried under a stream of nitrogen and dissolved in $\sim 1.7 \mathrm{~mL}$ of $\mathrm{MeOH}$. Each derivatized standard was injected individually $(0.7 \mu \mathrm{L})$ onto the UPLC. Also, aliquots of all of the derivatized standards were combined to give a mixed standard, which was injected too. UPLC conditions were $10-70 \% \mathrm{MeOH}$ in $0.1 \%$ of formic acid in $\mathrm{H}_{2} \mathrm{O}$ over $10 \mathrm{~min}$ on a $\mathrm{BEH}$ column, and the eluent was monitored at $340 \mathrm{~nm}$.

To generate the digested and derivatized peptaibols, approximately $0.2-0.3 \mathrm{mg}$ of compounds $1-3$ were weighed separately into $2 \mathrm{~mL}$ reaction vials, to which was added $0.5 \mathrm{~mL}$ of $6 \mathrm{~N} \mathrm{HCl}$. The compounds were hydrolyzed at $90{ }^{\circ} \mathrm{C}$ for $24 \mathrm{~h}$, at which time they were evaporated under a stream of nitrogen. To each hydrolysis product was then added $25 \mu \mathrm{L}$ of $\mathrm{H}_{2} \mathrm{O}, 10 \mu \mathrm{L}$ of $1 \mathrm{M} \mathrm{NaHCO}_{3}$, and $50 \mu \mathrm{L}$ of $1 \%$ Marfey's reagent in acetone. The reaction mixtures were agitated at $40{ }^{\circ} \mathrm{C}$ for $1 \mathrm{~h}$. The reactions were halted by the addition of $5 \mu \mathrm{L}$ of $2 \mathrm{~N} \mathrm{HCl}$. The mixtures were dried under a stream of nitrogen and brought up in $\sim 200 \mu \mathrm{L}$ of $\mathrm{MeOH}$ and injected onto the UPLC using the same conditions as for the standards (Figures S7-S10).

\section{ASSOCIATED CONTENT}

\section{S Supporting Information}

The Supporting Information is available free of charge on the ACS Publications website at DOI: 10.1021/acs.jnatprod.7b00189.

Molecular phylogenetic trees of T. arundinaceum and T. albolutescens; culture conditions of strains MSX70741 and MSX57715; experimental procedures; 1D and 2D NMR spectra and tabulated data of compounds 1-3; HRESIMS spectra of compounds 1-3; and Marfey's analysis of standards and compounds 1-3 (PDF)

\section{AUTHOR INFORMATION}

\section{Corresponding Author}

*E-mail: Nicholas_Oberlies@uncg.edu. Tel: 336-334-5474.

\section{ORCID 1}

Nicholas H. Oberlies: 0000-0002-0354-8464

\section{Notes}

The authors declare no competing financial interest.

\section{ACKNOWLEDGMENTS}

This research was supported via grant P01 CA125066 from the National Cancer Institute/National Institutes of Health, Bethesda, MD, USA. The high-resolution mass spectrometry data were acquired in the Triad Mass Spectrometry Laboratory at the University of North Carolina at Greensboro, Greensboro, NC, USA. We thank Drs. V. Kertesz and G. J. Van Berkel (Mass Spectrometry and Laser Spectroscopy Group, Chemical Sciences Division, Oak Ridge National Laboratory, Oak Ridge, TN, USA) for inspiration and guidance with the droplet-LMJSSP.

\section{REFERENCES}

(1) Dictionary of Natural Products. Taylor \& Francis Group. Available at the following: http://dnp.chemnetbase.com/.

(2) Kinghorn, A. D.; De Blanco, E. J. C.; Lucas, D. M.; Rakotondraibe, H. L.; Orjala, J.; Soejarto, D. D.; Oberlies, N. H.; Pearce, C. J.; Wani, M. C.; Stockwell, B. R.; Burdette, J. E.; Swanson, S. M.; Fuchs, J. R.; Phelps, M. A.; Xu, L.; Zhang, X.; Shen, Y. Y. Anticancer Res. 2016, 36, 5623-5637.

(3) Chung, W. J.; Vanderwal, C. D. Angew. Chem., Int. Ed. 2016, 55, 4396-4434.

(4) Harper, D. B.; O’Hagan, D. Nat. Prod. Rep. 1994, 11, 123-133.

(5) O'Hagan, D.; Harper, D. B. J. Fluorine Chem. 1999, 100, 127133

(6) Deng, H.; O’Hagan, D.; Schaffrath, C. Nat. Prod. Rep. 2004, 21, $773-784$.

(7) O’Hagan, D.; Deng, H. Chem. Rev. 2015, 115, 634-649.

(8) Harvey, A. L.; Edrada-Ebel, R.; Quinn, R. J. Nat. Rev. Drug Discovery 2015, 14, 111-129.

(9) Newman, D. J.; Cragg, G. M. Planta Med. 2016, 82, 775-789.

(10) Newman, D. J.; Cragg, G. M. J. Nat. Prod. 2016, 79, 629-661.

(11) Crane, E. A.; Gademann, K. Angew. Chem., Int. Ed. 2016, 55, $3882-3902$.

(12) Ojima, I. Fluorine in Medicinal Chemistry and Chemical Biology; John Wiley \& Sons, Ltd: Hoboken, NJ, 2009; pp 527-583.

(13) Zhou, Y.; Wang, J.; Gu, Z.; Wang, S.; Zhu, W.; Acena, J. L.; Soloshonok, V. A.; Izawa, K.; Liu, H. Chem. Rev. 2016, 116, 422-518.

(14) Wang, J.; Sanchez-Rosello, M.; Acena, J. L.; del Pozo, C.; Sorochinsky, A. E.; Fustero, S.; Soloshonok, V. A.; Liu, H. Chem. Rev. 2014, 114, 2432-2506.

(15) C\&EN. C\&EN Supplement. The Top 50 Drugs of 2014; American Chemical Society: Washington, DC, 2014; Vol. Supplement, September, 2014; p 37.

(16) Evans, B. E.; Rittle, K. E.; Bock, M. G.; DiPardo, R. M.; Freidinger, R. M.; Whitter, W. L.; Lundell, G. F.; Veber, D. F.; Anderson, P. S.; Chang, R. S. L.; et al. J. Med. Chem. 1988, 31, 22352246.

(17) Nicolaou, K. C.; Pfefferkorn, J. A.; Roecker, A. J.; Cao, G. Q.; Barluenga, S.; Mitchell, H. J. J. Am. Chem. Soc. 2000, 122, 9939-9953.

(18) Newman, D. J. J. Med. Chem. 2008, 51, 2589-2599.

(19) Ojima, I. J. Org. Chem. 2013, 78, 6358-6383.

(20) Gillis, E. P.; Eastman, K. J.; Hill, M. D.; Donnelly, D. J.; Meanwell, N. A. J. Med. Chem. 2015, 58, 8315-8359.

(21) Park, B. K.; Kitteringham, N. R.; O’Neill, P. M. Annu. Rev. Pharmacol. Toxicol. 2001, 41, 443-470.

(22) Deng, X.; Kokkonda, S.; El Mazouni, F.; White, J.; Burrows, J. N.; Kaminsky, W.; Charman, S. A.; Matthews, D.; Rathod, P. K.; Phillips, M. A. J. Med. Chem. 2014, 57, 5381-5394.

(23) Liang, T.; Neumann, C. N.; Ritter, T. Angew. Chem., Int. Ed. 2013, 52, 8214-8264.

(24) Champagne, P. A.; Desroches, J.; Hamel, J. D.; Vandamme, M.; Paquin, J. F. Chem. Rev. 2015, 115, 9073-9174.

(25) Eustaquio, A. S.; O’Hagan, D.; Moore, B. S. J. Nat. Prod. 2010, $73,378-382$.

(26) Thiericke, R.; Rohr, J. Nat. Prod. Rep. 1993, 10, 265-289.

(27) Walker, M. C.; Wen, M.; Weeks, A. M.; Chang, M. C. ACS Chem. Biol. 2012, 7, 1576-1585.

(28) Walker, M. C.; Thuronyi, B. W.; Charkoudian, L. K.; Lowry, B.; Khosla, C.; Chang, M. C. Science 2013, 341, 1089-1094.

(29) Walker, M. C.; Chang, M. C. Chem. Soc. Rev. 2014, 43, 65276536.

(30) Thuronyi, B. W.; Chang, M. C. Acc. Chem. Res. 2015, 48, 584592.

(31) Kobel, H.; Traber, R. Eur. J. Appl. Microbiol. Biotechnol. 1982, 14, 237-240.

(32) Traber, R.; Hofmann, H.; Kobel, H. J. Antibiot. 1989, 42, 591597.

(33) Weist, S.; Bister, B.; Puk, O.; Bischoff, D.; Pelzer, S.; Nicholson, G. J.; Wohlleben, W.; Jung, G.; Sussmuth, R. D. Angew. Chem., Int. Ed. 2002, 41, 3383-3385. 
(34) Runguphan, W.; Maresh, J. J.; O’Connor, S. E. Proc. Natl. Acad. Sci. U. S. A. 2009, 106, 13673-13678.

(35) Goss, R. J.; Lanceron, S.; Deb Roy, A.; Sprague, S.; Nur-e-Alam, M.; Hughes, D. L.; Wilkinson, B.; Moss, S. J. ChemBioChem 2010, 11, 698-702.

(36) Rosén, J.; Gottfries, J.; Muresan, S.; Backlund, A.; Oprea, T. I. J. Med. Chem. 2009, 52, 1953-1962.

(37) González-Medina, M.; Prieto-Martínez, F. D.; Naveja, J. J.; Méndez-Lucio, O.; El-Elimat, T.; Pearce, C. J.; Oberlies, N. H.; Figueroa, M.; Medina-Franco, J. L. Future Med. Chem. 2016, 8, 13991412.

(38) Ayers, S.; Ehrmann, B. M.; Adcock, A. F.; Kroll, D. J.; Carcache de Blanco, E. J.; Shen, Q.; Swanson, S. M.; Falkinham, J. O., 3rd; Wani, M. C.; Mitchell, S. M.; Pearce, C. J.; Oberlies, N. H. J. Pept. Sci. 2012, $18,500-510$.

(39) Stoppacher, N.; Neumann, N. K.; Burgstaller, L.; Zeilinger, S.; Degenkolb, T.; Bruckner, H.; Schuhmacher, R. Chem. Biodiversity 2013, 10, 734-743.

(40) Ben Haj Salah, K.; Inguimbert, N. Org. Lett. 2014, 16, 17831785.

(41) Neumann, N. K.; Stoppacher, N.; Zeilinger, S.; Degenkolb, T.; Bruckner, H.; Schuhmacher, R. Chem. Biodiversity 2015, 12, 743-751.

(42) Fringeli, U. P.; Fringeli, M. Proc. Natl. Acad. Sci. U. S. A. 1979, 76, 3852-3856.

(43) Schiell, M.; Hofmann, J.; Kurz, M.; Schmidt, F. R.; Veriest, L.; Vogel, M.; Wink, J.; Seibert, G. J. Antibiot. 2001, 54, 220-233.

(44) Vedovato, N.; Baldini, C.; Toniolo, C.; Rispoli, G. Chem. Biodiversity 2007, 4, 1338-1346.

(45) Sica, V. P.; Raja, H. A.; El-Elimat, T.; Kertesz, V.; Van Berkel, G. J.; Pearce, C. J.; Oberlies, N. H. J. Nat. Prod. 2015, 78, 1926-1936.

(46) Xu, Y.; Zhan, J.; Wijeratne, E. M. K.; Burns, A. M.; Gunatilaka, A. A. L.; Molnár, I. J. Nat. Prod. 2007, 70, 1467-1471.

(47) Igarashi, Y.; Yabuta, Y.; Sekine, A.; Fujii, K.; Harada, K.; Oikawa, T.; Sato, M.; Furumai, T.; Oki, T. J. Antibiot. 2004, 57, 748-754.

(48) Winn, M.; Fyans, J. K.; Zhuo, Y.; Micklefield, J. Nat. Prod. Rep. 2016, 33, 317-347.

(49) Ayers, S.; Ehrmann, B. M.; Adcock, A. F.; Kroll, D. J.; Wani, M. C.; Pearce, C. J.; Oberlies, N. H. Tetrahedron Lett. 2011, 52, 57335735.

(50) Ayers, S.; Graf, T. N.; Adcock, A. F.; Kroll, D. J.; Shen, Q.; Swanson, S. M.; Wani, M. C.; Darveaux, B. A.; Pearce, C. J.; Oberlies, N. H. Tetrahedron Lett. 2011, 52, 5128-5230.

(51) Figueroa, M.; Graf, T. N.; Ayers, S.; Adcock, A. F.; Kroll, D. J.; Yang, J.; Swanson, S. M.; Munoz-Acuna, U.; Carcache de Blanco, E. J.; Agrawal, R.; Wani, M. C.; Darveaux, B. A.; Pearce, C. J.; Oberlies, N. H. J. Antibiot. 2012, 65, 559-564.

(52) El-Elimat, T.; Figueroa, M.; Raja, H. A.; Graf, T. N.; Swanson, S. M.; Falkinham, J. O., 3rd; Wani, M. C.; Pearce, C. J.; Oberlies, N. H. Eur. J. Org. Chem. 2015, 2015, 109-121.

(53) Figueroa, M.; Raja, H.; Falkinham, J. O., 3rd; Adcock, A. F.; Kroll, D. J.; Wani, M. C.; Pearce, C. J.; Oberlies, N. H. J. Nat. Prod. 2013, 76, 1007-1015.

(54) Liu, D.; Lin, H.; Proksch, P.; Tang, X.; Shao, Z.; Lin, W. Org. Lett. 2015, 17, 1220-1223.

(55) Quagliato, D. A.; Andrae, P. M.; Matelan, E. M. J. Org. Chem. 2000, 65, 5037-5042.

(56) Ayers, S.; Graf, T. N.; Adcock, A. F.; Kroll, D. J.; Matthew, S.; Carcache de Blanco, E. J.; Shen, Q.; Swanson, S. M.; Wani, M. C.; Pearce, C. J.; Oberlies, N. H. J. Nat. Prod. 2011, 74, 1126-1131.

(57) Ayers, S.; Graf, T. N.; Adcock, A. F.; Kroll, D. J.; Shen, Q.; Swanson, S. M.; Matthew, S.; Carcache de Blanco, E. J.; Wani, M. C.; Darveaux, B. A.; Pearce, C. J.; Oberlies, N. H. J. Antibiot. 2012, 65, 38.

(58) El-Elimat, T.; Raja, H. A.; Day, C. S.; Chen, W. L.; Swanson, S. M.; Oberlies, N. H. J. Nat. Prod. 2014, 77, 2088-2098.

(59) Goss, R. J.; Shankar, S.; Fayad, A. A. Nat. Prod. Rep. 2012, 29, $870-889$.

(60) David, B.; Wolfender, J.-L.; Dias, D. A. Phytochem. Rev. 2015, 14, 299-315.
(61) Amirkia, V.; Heinrich, M. Front. Pharmacol. 2015, 6, 1-8.

(62) Eyal, H. B. Steef Boerrigter. See the following: www.straffordpub. $\mathrm{com} /$ products/drug-substance-patents-leveraging-new-fda-guidanceprotecting-composition-of-matter-patents-drafting-solid-form-claims2016-11-01 (accessed 2016).

(63) El-Elimat, T.; Figueroa, M.; Raja, H. A.; Adcock, A. F.; Kroll, D. J.; Swanson, S. M.; Wani, M. C.; Pearce, C. J.; Oberlies, N. H. Tetrahedron Lett. 2013, 54, 4300-4302.

(64) El-Elimat, T.; Figueroa, M.; Raja, H. A.; Graf, T. N.; Adcock, A. F.; Kroll, D. J.; Day, C. S.; Wani, M. C.; Pearce, C. J.; Oberlies, N. H. J. Nat. Prod. 2013, 76, 382-387.

(65) Raja, H. A.; Miller, A. N.; Pearce, C. J.; Oberlies, N. H. J. Nat. Prod. 2017, 80, 756-770. 